\title{
B[OЛОГ[M] MAIST]
}

DOI: 10.26693/jmbs03.06.275

УдК 613.8/665.353.3(048.8)

Антіпова Р. В., Комісова Т. Є., Сак А. Є.

РИЗИК ВИНИКНЕННЯ ПОРУШЕННЯ ЗДОРОВ'Я ЛЮДИНИ ПРИ СПОЖИВАННІ ПАЛЬМОВОЇ ОЛІЇ

\author{
Харківський національний педагогічний університет ім. Г. С. Сковороди, Україна
}

antipowaraja@i.ua

Наведено основні фрізико-хімічні властивості пальмової олії, ії̈ застосування у харчовій промисловості. Розглянуто проблему впливу пальмової олії на здоров'я людини. Проаналізовано сучасні дослідження стосовно безпеки її застосування. Показано, що тривалий прийом пальмової олії призводить, в першу чергу, до порушення функції серцево-судинної, імунної систем, викликає неоднозначні зміни в репродуктивній системі. Зроблено висновки про необхідність подальшого дослідження впливу пальмової олії на системи організму, зокрема, на репродуктивну систему.

Ключові слова: пальмова олія, насичені жирні кислоти, серцево-судинні захворювання.

Зв'язок роботи 3 науковими програмами, планами, темами. Практична частина дослідження ефекту впливу пальмової олії на організм людини запланована в рамках науково-дослідної роботи кафредри анатомії і фрізіології людини ім. профр. Я. Р. Синельникова «Вплив факторів навколишнього середовища на морфо-функціональний стан організму», № держ. реєстрації 0187.0228336. Тема прийнята рішенням вченої ради ХНПУ ім. Г. С. Сковороди.

Вступ. В даний час пальмова олія це найбільш поширений вид рослинного жиру в світі, використання якого в харчовій промисловості зростає 3 кожним роком. Виробництво пальмової олії 3 2015 р. перевищило виробництво соєвої олії та рапсової і зайняло перше місце серед виробництва рослинних олій, випереджаючи в 2,5 рази виробництво, навіть, соняшникової олії [1]. На сьогоднішній день пальмову олію включають до складу майже всіх харчових продуктів від кондитерських виробів до молочної продукції. Ї̈̈ можна зустріти в ре- цептурі шоколаду, батончиків, йогуртів, солодких сирків, маргарину, твердого та плавленого сиру, морозива, соусів, вареників, тощо. Так, найбільший в світі виробник продуктів харчування компанія Nestlé закуповує 420 тисяч тонн пальмової олії на рік.

Використання пальмової олії обумовлено ії̈ фрізико-хімічними властивостями, що забезпечують здатність залишатися в твердому і напівтвердому стані при кімнатній температурі, на відміну від більшості олій рослинного походження [2]. Ці властивості пальмової олії і дозволили виробникам застосовувати ії̈ як природного замінника частково гідрогенізованих рослинних жирів.

Разом $з$ тим, Всесвітня організація охорони здоров'я офіційно рекомендувала зменшити споживання насичених жирних кислот, при цьому пальмову олію порівнюють за рівнем небезпеки $з$ такими продуктами харчування, як вершкове масло і вершки, м'ясо, яйця, шоколад і сало [11].

Метою роботи було дослідити позитивні та негативні особливості використання пальмової олії у харчовій промисловості, проаналізувати сучасні наукові дані про вплив пальмової олії на організм людини.

Пальмова олія $є$ продуктом рослинного походження, що отримують з м'ясистої частини плодів олійної пальми (Elaeisguineensis). Олія 3 насіння цієї пальми називається пальмоядрова олія.

На сьогоднішній день світовими лідерами 3 виробництва цієї олії є Малайзія (5,0 млн т), Індонезія (1,8 млн т) і Нігерія (750 тис. т).

Пальмова олія відрізняється від інших рослинних олій високим вмістом насичених жирних кислот, які складають приблизно половину загального вмісту жиру. Головною насиченою жирною кислотою 
пальмової олії є пальмітинова кислота, яка становить 41-50\%. Слід зазначити, що це основна жирна кислота, яка зустрічається в продуктах тваринного походження і в деяких овочах. Також вона $€$ основним компонентом жирів грудного молока. Разом з тим, пальмова олія відрізняється високим вмістом (35-45\%) олеїнової кислоти, яка $€$ основною мононенасиченою жирною кислотою. При цьому вміст незамінних поліненасичених жирних кислот в пальмовій олії незначне, а така як лінолева взагалі відсутня [1]. Через незбалансованість складу жирних кислот пальмова олія не є цінним харчовим продуктом і може застосовуватися в харчуванні тільки в комбінації з оліями, що багаті на поліненасичені жирні кислоти омега-3, омега-6, а саме 3 льняною і кедровою.

Аналіз наукових експериментальних і клінічних досліджень показав, що на сьогодні в харчовій промисловості використовується звичайна пальмова олія, що виготовляється 3 ядра (пальмоядерна) та червона пальмова олія, її отримують із м'якоті плоду. Весь вітамін А міститься в деревній м'якоті плоду і він переробляється окремо від ядра плода. Тому найдешевші сорти звичайної пальмової олії не містять вітаміну А. Така олія має сірувато-білий, а не червоний відтінок, тому що весь вітамін А при переробці потрапляє до червоної пальмової олії $[1,2,5]$.

Результати експериментальних і клінічних робіт свідчать, що застосування звичайної пальмової олії збільшує ризик розвитку серцево-судинної патології. Дані дослідження, проведеного в Коста-Ріці в 2005, які включали велике кількість обстежуваних, показали, що використання в харчуванні пальмової олії (вміст 1,5\% транс-жирів) навіть у порівнянні з соєвою олією (вміст транс-жирів 5\%), збільшує ймовірність інфаркту міокарда на 33\% [12]. Аналіз моніторингу 23 країн, проведеного в 2011 році, показує, що кожен кілограм пальмової олії, який вживається щорічно, достовірно збільшував смертність від ішемічної хвороби серця (68 смертельних випадків на 100000) [8]. Тому Всесвітня організація охорони здоров'я рекомендувала зменшити вживання пальмової олії через високий вміст насичених жирних кислот, як одного $з$ факторів ризику серцево-судинних захворювань [11].

Проведено й експериментальні дослідження на мишах по вивченню впливу пальмової олії на рівень артеріального тиску [8, 9, 10], морфометрію аорти і клітинну адгезію молекул судин [9]. Показано несприятливий вплив пальмової олії на оновлення судин, розвиток запалення і оксидантного стресу, підвищення артеріального тиску через шість місяців споживання неодноразово нагрітої пальмової олії [6].

Актуальність проведення комплексних експериментальних досліджень впливу пальмової олії на різні системи організму зростає з кожним днем. Так, є дані щодо впливу тривалого надмірного застосування в їжу пальмової олії на морфологічні зміни в первинному лімфоїдному органі тимусі [3]. Експерименти проведені на моделі аліментарного ожиріння з використанням пальмової олії в динаміці на органометричні показники тимуса щурів самців і самок різних періодів онтогенезу. В результаті дослідження автори показали, що додавання в харчовий раціон пальмової олії в дозі 30 г/кг щодня протягом шести тижнів призводить до надлишку маси тіла щурів всіх вікових груп, властивому аліментарному ожирінні II-III ступеня [3]. Найбільш виражений приріст маси тіла (в 1,95 рази) в умовах експерименту встановлено у групі статевонезрілих щурів. Прискорена вікова інволюція тимуса у щурів, які отримували в надлишку з кормом пальмову олію, на думку авторів, може бути обумовлена тим, що пальмітинова кислота, з якої на 50\% складається пальмова олія, не здатна повністю виводиться 3 організму і депонується в тимусі [3].

Вплив пальмової олії на порушення метаболічних процесів і фрормування ожиріння також показано в іншому експериментальному дослідженні. У ньому тривалий прийом в їжу пальмової олії протягом шести тижнів призводив у щурів до збільшення маси тіла в динаміці і виникнення аліментарного ожиріння II-III ступеня. Навіть скасування прийому пальмової олії у тварин не призвело до втрати маси тіла [3].

Таким чином, отримані результати проведених експериментальних досліджень доводять негативний вплив пальмової олії на метаболічні процеси, наслідком яких $є$ надмірна вага й ожиріння. Так, за останні десятиліття спостерігається прогресивне збільшення кількості випадків надмірної ваги і ожиріння як серед дорослого населення (до 35\%), так і серед дітей та підлітків (до 25\%). І це зростання становить 10\% від попередніх за кожні 10 років $[6,7]$. Разом з тим відомо, що надмірна вага й ожиріння $€$ вагомими чинниками в розвитку серцевосудинної патології.

Слід зазначити, що для країн Африки і Південно-Східної Азії з високим споживанням звичайної пальмової олії $€$ проблема дефріциту вітаміну $A$ [13]. Відомо, що дефіцит вітаміну А викликає нічну сліпоту, і виступає фрактором ризику низькі захворювань особливо у дітей дошкільного віку та вагітних жінок.

Експериментальні дослідження показують різні ефекти впливу пальмової олії на репродуктивну функцію. Так, тридцять самців щурів лінії Wistar, розділених на п'ять груп по шість щурів у кожній, отримували протягом двох місяців різні форми зразків пальмової олії, а саме: пастеризований 
пальмовий сік, пальмова олія, заморожений пальмовий сік, свіжий пальмовий сік, а контрольна група отримувала тільки воду. Результати дослідження показали, що прийом таких форм пальмової олії покращує фертильність у самців. Однак, її споживання протягом тривалого періоду (більш двох місяців) призводить до некротичних змін в сім'яниках. Також слід зазначити, що прийом пастеризованого пальмового соку негативно впливає на репродуктивні показники у самців [14].

Червона пальмова олія на відміну від звичайної пальмової олії та інших рослинних жирів має антиоксидантні властивості завдяки високому вмісту в ній комплексу токоферолів (вітамін Е) і токотрієнолів (близько 80 мг/100 г), каротиноїдів (100120 мг/100г), які $є$ попередниками вітаміну А, а також містить кофермент $Q(100,43$ мг/100г) [2, 5]. Однак слід відмітити, що частка червоної пальмової олії, яка поставляється на споживацький ринок, мізерно мала, оскільки біохімічні компанії, розуміючи надзвичайну цінність червоної пальмової олії, навчилися розділяти пальмову олію за сортами.

Червона пальмова олія в комбінації з ройбушем (Aspalathuslinearis), надають протизапальний ефект на системному рівні, що показано в експериментальних дослідженнях на щурах [13]. Це пов'язано з тим, що червона пальмова олія багата незамінними жирними кислотами і жиророзчинними антиоксидантами, а ройбуш містить поліфенолічні комплекси з унікальним складом флавоноїдів. Тому комбінація цих двох натуральних компонентів має потенціал, щоби збільшити спектр доступних дієтичних антиоксидантів [13].

Заключення. Аналіз сучасної наукової літератури показує, що рафрінована пальмова олія та пальмова олія, яку піддавали термообробці, негативно впливає на здоров'я людини, зокрема на її імунну та серцево-судинну системи.

Перспективи подальших досліджень. 3 урахуванням постійно зростаючого споживання пальмової олії у світі та інтеграції України у світову економіку, існує необхідність проведення науковоекспериментальних досліджень впливу пальмової олії на морфо-функціональний стан організму людини при її вживанні. Нами планується проведення експерименту з метою вивчення впливу пальмової олії на репродуктивну функцію.

\section{References}

1. Anisimov AA, Rumiantsev VY. Palm oil and its role in the production of products. Fat-and-oil industry. 2002; 2: $22-4$.

2. Harutyunyan NS, Kornen EP, Nesterova EA. The ratification of oils and fats: theoretical basis, practice, technology, equipment. SPb: GIORD, 2004. 288 p. [Russian]

3. Bibik EYu, Gayvoronskaya YV. Influence of excess consumption of palm oil on organometric indices of thymus in different periods of ontogenesis. International Sci Int. 2015; Iss IX(16): 81-6.

4. Koveshhnikov VG, Bibik EYu. Functional morphology of the immune system organs. Lugansk: The Virtual reality, 2007. 172 p. [Russian]

5. Tyshchenko EA, Tereshchuk LV, Pavelyeva EG. Investigation of the composition and properties of red palm oil used as a functional component of emulsion creams. Techniques and technology of food production. 2010; 1(16): 43-5. [Russian]

6. Drake AJ, Reynolds RM. Impact of maternal obesity on offspring obesity and cardiometabolic risk. Reproduction. 2010; 140(3): 387-98. PMID: 20562299. DOI: 10.1530/REP-10-0077

7. Kearney PM, Whelton M, Reynolds K, Muntner P, Whelton PK, He J. Global burden of hypertension: analysis of worldwide data. Lancet. 2005 Jan 15-21; 365(9455): 217-23. PMID: 15652604. DOI: 10.1016/S0140-6736(05)17741-1

8. Leong XF, Aishah A, Nor Aini U, Das S, Jaarin K. Heated palm oil causes rise in blood pressure and cardiac changes in heart muscle in experimental rats. Arch Med Res. 2008 Aug; 39(6): 567-72. PMID: 18662587. doi: 10.1016/ j.arcmed.2008.04.009

9. Ng CY, Kamisah Y, Faizah O, Jubri Z, Qodriyah HM, Jaarin K. Involvement of inflammation and adverse vascular remodeling in the blood pressure raising effect of repeatedly heated palm oil in rats. Int $J$ Vasc Med. 2012; 2012: 404025. PMID 22778962. PMCID PMC3388444. doi: 10.1155/2012/404025

10. Jaarin K, Mustafa MR, Leong XF. The effets of heated vegetable oils in blood pressure in rats. Clinics (San-Paulo). 2011; 66(12): 2125-32. PMID: 22189740. PMCID: PMC3226610

11. Chen BK, Seligman B, Farquhar JW, Goldhaber-Fiebert JD. Multi-Country analysis of palm oil consumption and cardiovascular disease mortality for countries at different stages of economic development: 1980-1997. Global Health. 2011 Dec 16; 7: 45. PMID: 22177258. PMCID: PMC3271960. doi: 10.1186/1744-8603-7-45.

12. Kabagambe EK, Baylin A, Ascherio A, Campos $\mathrm{H}$. The type of oil used tor cooking is associated withthe risk of nonfatal acute myocardial infarction in Costa Rica. J Nutr. 2005 Nov; 135(11): 2674-9. PMID: 16251629. DOI: 10.1093/ jn/135.11.2674

13. Katengua-Thamahane E, Marnewick JL, Ajuwon OR, Chegou NN, Szücs G, Ferdinandy P, Csont T, Csonka C, Van Rooyen J. The combination of red palm oil and rooibos show anti-inflammatory effects in rats. J Inflamm (Lond). 2014 Dec 20; 11(1): 41. PMID: 25598708. PMCID: PMC4297406. doi: 10.1186/s12950-014-0041-4

14. Ikegwu TM, Okafor GI, Ochiogu IS. Effect of preservation methods of oil palm sap (Elaeis guineensis) on the reproductive indices of male Wistar rats J Med Food. 2014 Dec; 17(12): 1368-74. PMID: 25101691. PMCID: PMC4259188. doi: $10.1089 /$ jmf.2013.0087 
УДК 613.8/665.353.3(048.8)

\section{РИСК НАРУШЕНИЯ ЗДОРОВЬЯ ЧЕЛОВЕКА ПРИ ПОТРЕБЛЕНИИ ПАЛЬМОВОГО МАСЛА}

Антипова Р. В., Комисова Т. Е., Сак А. Е.

Резюме. Приведены основные фризико-химические свойства пальмового масла, его использования в пищевой промышленности. Рассмотрена проблема влияния пальмового масла на здоровье человека. Проанализированы современные исследования относительно безопасности его использования. Показано, что длительный приём пальмового масла приводит, в первую очередь, к нарушению функции сердечно-сосудистой, иммунной систем, вызывает неоднозначные изменения в репродуктивной системе. Сделаны выводы о необходимости дальнейшего исследования влияния пальмового масла на системы организма, в частности, на репродуктивную систему.

Ключевые слова: пальмовое масло, насыщенные жирные кислоты, сердечно-сосудистые заболевания.

UDC 613.8/665.353.3(048.8)

The Risk of Human Health Damage when Consuming Palm Oil

Antipova R., Komisova T., Sak A.

Abstract. The paper presents basic physical and chemical properties of palm oil, its application in the food industry. The problem of the palm oil influence on human health is considered. Palm oil is currently the most common type of vegetable fat in the world, the use of which in the food industry is increasing every year. Production of palm oil from 2015 exceeded the production of soybean oil and rapeseed and took the first place among the production of vegetable oils, ahead of 2.5 times production, even sunflower oil .Today palm oil is included in almost all food products from confectionery to dairy products. It can be found in the recipes of chocolate, bars, yoghurts, sweet cheeses, margarine, hard and fermented cheese, ice cream, sauces, dumplings, and so on. Thus, Nestlé, the world's largest food producer, buys 420,000 tons of palm oil per year. The palm oil is used due to its physical and chemical properties, which provide the ability to remain in solid and semi-solid state at room temperature, unlike most vegetable oils. These properties of palm oil allow manufacturers to apply it as a natural substitute for partially hydrogenated vegetable fats. At the same time, the World Health Organization has officially recommended to reduce the consumption of saturated fatty acids, while palm oil is compared by the level of danger to such food products as butter and cream, meat, eggs, chocolate and lard. The analysis of scientific and experimental and clinical studies showed that palm kernel (palm kernel) and red palm oil used in the food industry today are obtained from the pulp of the fetus. All vitamin A is found in fetal wood pulp and is processed separately from the fetal nucleus. Therefore, the cheapest varieties of ordinary palm oil do not contain vitamin A. This oil has a grayish-white, rather than a red hue, because all the vitamin A in the processing goes to the red palm oil. The obtained results of experimental researches prove the negative influence of palm oil on metabolic processes, the result of which is overweight and obesity. Thus, in recent decades there has been a progressive increase of the number of overweight and obesity cases both among adults (up to 35\%) and among children and adolescents (up to 25\%). And this growth is $10 \%$ from the previous for every 10 years. However, it is known that overweight and obesity are important factors in the development of cardiovascular diseases. It should be noted that for countries in Africa and Southeast Asia with high consumption of common palm oil, there is a problem of vitamin A deficiency. It is known that vitamin A deficiency causes night blindness, and acts as a risk factor for low disease, especially in preschool children and pregnant women. The urgency of conducting complex experimental studies of the influence of palm oil on different systems of the organism increases with each passing day. There is evidence of the effect of prolonged excessive use of palm oil on morphological changes in the primary lymphoid organ of thymus. Experimental studies show different effects of palm oil on reproductive function. Taking into account the ever-increasing consumption of palm oil in the world and Ukraine's integration into the world economy, there is a need for scientific and experimental research into the influence of palm oil on the morpho-functional state of the human body. The obtained results showed that prolonged use of palm oil led, first of all, to the violation of cardiovascular and immune systems, causing ambiguous changes in the reproductive system. The conclusion was made on the necessity of further study of the influence of palm oil on the organism, in particular, on the reproduction. We are planning an experimental study of the palm oil effects on reproductive function.

Keywords: palm oil, saturated fatty acids, cardiovascular diseases.

The authors of this study confirm that the research and publication of the results were not associated with any conflicts regarding commercial or financial relations, relations with organizations and/or individuals who may have been related to the study, and interrelations of coauthors of the article. 